\title{
PERAN JUMANTIK PADA KEJADIAN DEMAM BERDARAH DENGUE: STUDI POTONG LINTANG DI UPTD PUSKESMAS KUTA SELATAN
}

\author{
The Role of Jumantik in the Incidence of Dengue Hemorrhagic Fever: Cross- \\ Cutting Study at the UPTD Puskesmas Kuta Selatan
}

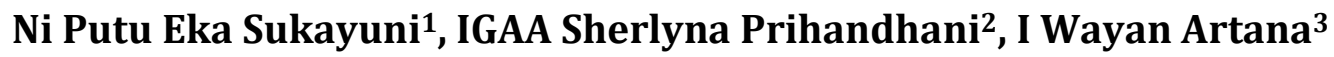 \\ STIKES Bina Usada Bali ${ }^{1,2,3}$ \\ Korespondensi: putueka.sukayuni@gmail.com
}

\begin{abstract}
Jumantik plays a role in the early vigilance system to monitor the presence and inhibit the development of the Dengue Hemorrhagic Fever (Dengue) mosquito vector. Jumantik cadres are expected to be active in monitoring their environment to reduce the number of dengue cases. However, in 2020 there will be an increase in dengue cases in South Kuta. This study purposed to determine the correlation between the role of jumantik and the incidence of dengue fever at the UPTD Puskesmas Kuta Selatan.

This study used observational quantitative research with a cross-sectional design. The sample amounted to 67 jumantik selected by total sampling. Data were collected using a questionnaire and documentary sheet of DHF case reports. Data analysis used Rank Spearman's test.

It was found that the majority of jumantik's role was good (77.6\%) and the incidence of dengue fever decreased (74.6\%). The analysis shows that there is a significant relationship between the role of jumantik and the incidence of dengue fever in the UPTD Puskesmas Kuta Selatan with a moderate and positive correlation, which means the better the role of jumantik in carrying out their duties. The better the jumantik work, the incidence of dengue fever decreases ( $p$ value $0.002<\alpha 0.05$ and coefficient correlation of 0,427 ). It is recommended to the health office to carry out training and health education for jumantik on an ongoing basis which is carried out every one semester.
\end{abstract}

Keywords $\quad$ : Dengue Hemorrhagic Fever, Jumantik, DHF Cases

\section{PENDAHULUAN}

Demam Berdarah Dengue (DBD) merupakan penyakit yang ditemukan di daerah tropis dan sub-tropis. Sejak tahun 1968 sampai tahun 2009, World Health Organization (WHO) mencatat Indonesia sebagai negara dengan kasus DBD tertinggi di Asia Tenggara (Kemenkes RI, 2012). Tahun 2015, Bali sebagai provinsi dengan Incident Rate (IR) DBD tertinggi yaitu 208,7 per 100.000 penduduk (Infodatin, 2016). Dinas Kesehatan Kabupaten Badung mencatat, dalam kurun waktu lima tahun kasus DBD tertinggi terjadi pada tahun 2016 sebesar 3.949 kasus, menurun ditahun 2017 dan 2018. Namun, meningkat kembali di tahun 2019 dengan jumlah kasus DBD sebanyak 1.275. Wilayah dengan jumlah kasus tertinggi di Kabupaten Badung adalah wilayah kerja Puskesmas Kuta Selatan sebanyak 296 kasus tahun 2019 (Dinas Kesehatan Kab Badung, 2019).

Husnayain and Fuad (2019) menyatakan peran jumantik penting dalam sistem kewaspadaan dini DBD karena berfungsi untuk memantau keberadaan vektor penularnya. Keberhasilan kegiatan pemantauan lingkungan dalam kegiatan Pemberantasan Sarang Nyamuk (PSN) dapat diukur melalui angka bebas jentik $(\mathrm{ABJ})$, apabila $\mathrm{ABJ}$ lebih atau sama dengan 95\% diharapkan penularan DBD dapat dicegah atau dikurangi (Kemenkes RI, 2017). Namun, angka ABJ yang tinggi bisa 
juga disebabkan oleh jumantik yang kinerjanya kurang baik. Salah satu indikatornya adalah jumantik kurang teliti dalam melakukan survey (Pratamawati, 2012). Keaktifan peran jumantik dalam pemantauan, pengawasan dan edukasi yang dilakukan secara periodik merupakan kunci utama dalam meningkatkan keberhasilan pengendalian DBD dan mencegah terjadinya peningkatan kasus (Kemenkes RI, 2017). Namun, keaktifan jumantik dalam melaksanakan perannya juga dipengaruhi oleh faktor-faktor seperti tingkat pendidikan, masa kerja, motivasi kerja sehingga dapat mempengaruhi kinerja jumantik itu sendiri (Hadi et al., 2011). Serupa juga dikemukakan oleh (Tanjung, 2012) bahwa pada prakteknya sebagian jumantik hanya memantau jentik saja dan sebagian sudah melaksanakan pemantauan jentik, mencatat PJB dan penyuluhan.

Berdasarkan hasil studi pendahuluan, Kecamatan Kuta Selatan memiliki 67 jumantik. Sejak dibentuk pada tahun 2017, kasus DBD mengalami penurunan sebesar 83\% dibadingkan tahun 2016. Namun meningkat kembali di tahun 2019 sebanyak 296 kasus (Puskesmas Kuta Selatan, 2019). Bahkan tahun 2020 terjadi tren peningkatan pada bulan Januari hingga April kasus DBD mencapai 912 kasus (Puskesmas Kuta Selatan, 2020).

\section{KAJIAN TEORITIS}

Demam Berdarah Dengue (DBD) adalah penyakit yang ditularkan melalui gigitan nyamuk Aedes aegypty yang terinfeksi salah satu dari empat serotipe virus dengue, yang dapat terjadi pada bayi, anak-anak, maupun orang dewasa yang ditandai dengan gejala demam selama 314 hari setelah gigitan infektif (WHO, 2015). Sedangkan menurut Kemenkes RI (2012) menyatakan bahwa DBD merupakan penyakit yang disebabkan oleh virus Dengue yang ditularkan dari orang ke orang melalui gigitan nyamuk Aedes aegypty

Menurut Kemenkes RI ( 2012) pencegahan yang paling efektif dan efisien dalam penanggulangan DBD adalah kegiatan pemberantasan sarang nyamuk
(PSN) dengan cara 3 M Plus, yaitu: 1) Menguras, adalah membersihkan tempat yang sering dijadikan tempat penampungan air seperti bak mandi, ember air, tempat penampungan air minum, dan tempat penampungan air lemari es, 2) Menutup, yaitu menutup rapat-rapat tempat penampungan air seperti drum, kendi, toren air, dan sebagainya; dan 3) memanfaatkan kembali atau mendaur ulang barang bekas yang memiliki potensial untuk menjadi tempat perkembangbiakan nyamuk penular DBD. Adapun yang dimaksud dengan plus adalah segala bentuk kegiatan pencegahan, seperti: 1) menaburkan bubuk larvasida pada tempat penampungan air yang sulit dibersihkan, 2) menggunakan obat nyamuk atau anti nyamuk, 3) menggunakan kelambu saat tidur, 4) memelihara ikan pemangsa jentik nyamuk, 5) menanam tanaman pengusir nyamuk, 6) mengatur cahaya dan ventilasi dalam rumah, 7) menghindari kebiasaan menggantung pakaian di dalam rumah yang bisa menjadi tempat istirahat nyamuk. Selain itu juga dapat dilakukan dengan melakukan penyemprotan (fogging) yang dilakukan oleh tenaga kesehatan pada daerah-daerah yang mengalami kejadian DBD yang tinggi.

Selain Pemberantasan Sarang Nyamuk (PSN) 3M Plus, sejak Juni 2015 Kemenkes sudah mengenalkan program 1 rumah 1 Jumantik (juru pemantau jentik) untuk menurunkan angka kematian dan kesakitan akibat DBD. Gerakan ini merupakan salah satu upaya preventif mencegah Demam Berdarah Dengue (DBD) dari mulai pintu masuk negara sampai ke pintu rumah (Kemenkes RI, 2017).

Jumantik merupakan orang yang berasal dari masyarakat, yang diberikan pelatihan untuk melaksanakan pemeriksaan jentik secara berkala dan terus-menerus serta menggerakan masyarakat dalam melaksanakan pemberantasan sarang nyamuk DBD (Kemenkes RI, 2012). Kader jumantik merupakan kelompok kerja yang dibentuk untuk pemberantasan penyakit DBD di tingkat desa dalam wadah Lembaga Pemberdayaan Masyarakat (LPM) (Pratamawati, 2012). 
Baik buruknya pelaksanaan peran dan tugas jumantik sangat menentukan tinggi rendahnya kejadian DBD. Pelaksanaan peran jumantik sangat dipengaruhi oleh karakteristik jumantik itu sendiri seperti umur, pendidikan, motivasi, dan pengalaman. Selain itu, peningkatan atau penurunan kejadian DBD juga sangat ditentukan dari perilaku masyarakat sendiri tentang kepatuhan melaksanakan saran atau arahan dari jumantik

\section{KAJIAN EMPIRIS}

Penelitian Adnan and Siswani (2019) tentang peran kader jumantik yang mempengaruhi perilaku masyarakat dalam upaya pencegahan penyakit DBD di wilayah kerja Kelurahan Tebet Timur tahun 2019. Penelitian Deksriptive correlative dengan pendekatan crosssectional. Sampel diperoleh menggunakan stratified random sampling dengan jumlah sampel 109 orang. Pengumpulan data dilakukan dengan kuesioner, dan observasi data sekunder. Analisis menggunakan kai kuadrat /chisquare. Hasil penelitian menunjukan bahwa peran kader jumantik dalam pemberantasan sarang nyamuk, pemantauan jentik berkala dan pemberian penyuluhan berhubungan dengan perilaku masyarakat dalam upaya pencegahan penyakit DBD. Sedangkan pelaporan kasus DBD tidak beruhubungan. Penelitian Muliawati (2017) tentang hubungan pendidikan dan pelatihan Jumantik dengan keberhasilan Program PSN dalam rangka menurunkan angka kejadian DBD di Kelurahan Tanah Kalikedinding Kota Surabaya. Jenis penelitian analitik observasional dengan pendekatan cross sectional. Populasi penelitian adalah semua kader Jumantik yang terdapat di wilayah kerja Kelurahan Tanah Kalikedinding yaitu sebanyak 251 orang. Data dikumpulkan dengan kuesioner dan di uji dengan Uji statistik chi-square. Hasil penelitian menunjukkan ada hubungan pelatihan jumantik dengan keberhasilan Program Pemberantasan Sarang Nyamuk di Kelurahan Tanah Kalikedinding Kota Surabaya dan tidak ada hubungan pendidikan, pengetahuan, sikap dan perilaku Jumantik dengan keberhasilan Program Pemberantasan Sarang Nyamuk. Penelitian Natalia,
Sambuaga and Pandean (2017) tentang hubungan peran serta juru pemantau jentik (jumantik) dan Keberadaan jentik nyamuk Aedes aegypti Kecamatan Kalawat Kabupaten Minahasa Utara. Jenis Penelitian ini merupakan jenis penelitian analitik dengan pendekatan cross sectional studi, variabel dalam penelitian ini yaitu peran serta juru pemantau jentik dengan keberadaan jentik nyamuk Aedes aegypti di Kecamatan Kalawat. Hasil analisis statistik membuktikan bahwa ada hubungan antara peran serta Juru Pemantau Jentik dengan keberadaan jentik nyamuk Aedes aegypti.

\section{METODE PENELITIAN}

Penelitian ini adalah kuantitatif dengan pendekatan cross sectional. Sampel penelitian adalah semua jumantik di wilayah kerja UPTD Puskesmas Kuta Selatan sebanyak 67 orang dengan teknik Total sampling. Data dianalisis menggunakan uji statistik Spearman Rho dengan nilai signifikansi $\alpha=0,05$.

\section{HASIL DAN PEMBAHASAN}

\section{Peran Jumantik di UPTD Puskesmas Kuta Selatan}

Tabel 1 Distribusi Frekuensi Peran Jumantik di UPTD Puskesmas Kuta Selatan $(n=67)$

\begin{tabular}{lcc}
\hline $\begin{array}{l}\text { Peran } \\
\text { Jumantik }\end{array}$ & $\begin{array}{c}\text { Frekuensi } \\
\text { (f) }\end{array}$ & $\begin{array}{c}\text { Presentase } \\
\text { (\%) }\end{array}$ \\
\hline Baik & 52 & 77,6 \\
Cukup & 15 & 22,4 \\
Kurang & 0 & 0,0 \\
\hline
\end{tabular}

Berdasarkan tabel 1 di atas dapat diketahui dari 67 responden sebagian besar peran jumantik adalah baik yaitu sebanyak 52 orang $(77,6 \%)$.

\section{Kejadian DBD di UPTD Puskesmas Kuta Selatan}

Tabel 2 Distribusi Frekuensi Kejadian DBD di UPTD Puskesmas Kuta Selatan $(n=67)$ 


\begin{tabular}{lcc}
\hline $\begin{array}{l}\text { Kejadian } \\
\text { DBD }\end{array}$ & $\begin{array}{c}\text { Frekuensi } \\
\text { (f) }\end{array}$ & $\begin{array}{c}\text { Presentase } \\
\text { (\%) }\end{array}$ \\
\hline Menurun & 50 & 74,6 \\
Meningkat & 17 & 25,4 \\
\hline
\end{tabular}

Berdasarkan tabel 2 di atas dapat diketahui dari dari 67 responden (Banjar) sebagian besar kejadian DBD menurun terjadi pada 50 Banjar (74,6\%).

\section{Hubungan Peran Jumantik dengan Kejadian DBD di UPTD Puskesmas Kuta Selatan}

Tabel 3. Hubungan Peran Jumantik dengan Kejadian DBD di UPTD Puskesmas Kuta Selatan ( $\mathrm{n}=67)$

\begin{tabular}{lccc}
\hline \multicolumn{1}{c}{ Variabel } & N & r & $\begin{array}{c}\mathbf{p} \\
\text { value }\end{array}$ \\
\hline $\begin{array}{l}\text { Peran jumantik dan } \\
\text { Kejadian DBD }\end{array}$ & 67 & 0.427 & 0,002 \\
\hline
\end{tabular}

Tabel 3 menunjukkan hasil uji statistik Spearmans Rho dapat diketahui correlation coefficient 0,427 dan $\mathrm{p}$ value (Sig. (2-tailed)) sebesar 0,002, maka dapat disimpulkan bahwa $\mathrm{p}$ value $<\alpha$ $(0,05)$ yang artinya secara statistik ada hubungan yang signifikan antara peran jumantik dengan kejadian DBD di UPTD Puskesmas Kuta Selatan. Coefecient Correlation sebesar 0,427 menunjukkan korelasi yang sedang antar kedua variabel (0,40-0,599) dan sifat korelasi/hubungan yang positif atau searah yang artinya bahwa semakin baik peran jumantik dalam melaksanakan tugasnya maka semakin menurun kejadian DBD di UPTD Puskesmas Kuta Selatan.

\section{SIMPULAN DAN SARAN}

Ada hubungan yang signifikan antara peran jumantik dengan kejadian DBD di UPTD Puskesmas Kuta Selatan, semakin baik peran jumantik dalam melaksanakan tugasnya maka semakin menurun kejadian DBD di UPTD Puskesmas Kuta Selatan.

\section{DAFTAR PUSTAKA}

Adnan, A. B., \& Siswani, S. (2019). Peran Kader Jumantik Terhadap Perilaku Masyarakat Dalam Upaya Pencegahan Penyakit Demam Berdarah Dengue (Dbd) Di Wilayah Kerja Kelurahan Tebet Timur Tahun 2019. JUKMAS: Jurnal Untuk Masyarakat Sehat, 3(2), 204-218.

Dinas Kesehatan Kab Badung. (2019). Laporan Bulanan Program P2B2 Dinas Kesehatan Kabupaten Badung.

Hadi, M. C., Rusminingsih, N. K., \& Marwati, N. M. (2011). Peran Jumantik dalam menurunkan Insidens rate DBD di Denpasar. Jurnal Skala Husada, 12(1), 89-95.

Husnayain, A., \& Fuad, A. (2019). Menggunakan Google Trends untuk dukung sistem monitoring demam berdarah, bagaimana caranya?

Infodatin. (2016). Infodatin Dbd 2016 (1).Pdf.

Kemenkes RI. (2012). Pemberantasan sarang nyamuk demam berdarah dengue oleh juru pemantau jentik (jumantik). Kementrian Kesehatan R.I Direktorat Jendral Pengendalian Penyakit dan Penyehatan Lingkungan.

Kemenkes RI. (2015). Kementerian Kesehatan Republik Indonesia.

Kemenkes RI. (2017). Pedoman Demam Berdarah Dengue Indonesia.

Muliawati, E. (2017). Hubungan Pendidikan Dan Pelatihan Jumantik Dengan Keberhasilan Program Psn Di Kelurahan Tanah Kalikedinding Kota Surabaya. Jurnal Keperawatan Muhammadiyah, 1(2).

Natalia, M., Sambuaga, J. V. I., \& Pandean, M. M. (2017). Peran Serta Juru Pemantau Jentik (Jumantik) Dengan Keberadaan Jentik Nyamuk Aedes aegypti Di Kecamatan Kalawat Kabupaten Minahasa 
Utara. Jurnal Kesehatan Lingkungan, 7(1), 7-13.

Pratamawati, D. A. (2012). Peran Juru Pantau Jentik dalam Sistem Kewaspadaan Dini Demam Berdarah Dengue di Indonesia. Kesmas: National Public Health Journal, 6(6), 243. https://doi.org/10.21109/kesmas. v6i6.76

Puskesmas Kuta Selatan, T. M. (2019).
Profil UPT Puskesmas Kuta Selatan.

Puskesmas Kuta Selatan, T. M. (2020). Laporan Bulanan Program P2 DBD.

Tanjung, M. O. (2012). Perilaku Kader Jumantik Dalam Melaksanakan PSN DBD $3 M$ Plus Di Kelurahan Jomblang Kecamatan Candisari. 1(1), 1-8.

WHO. (2015). World Health Organization. 